\title{
A Probe into the Essentials of Legislation Planning of Municipal People's Congress
}

\author{
Senlin Huang, Qiang Ran \\ Neijiang normal college \\ Neijiang, Sichuan, 641100
}

\begin{abstract}
The Municipal People's Congress can set up standards upon local situation, however, it is a challenge to achieve the scientific, systematic and feasible requirements of the legislation. Based on the results of the legislative researches, this paper puts forward the main points of the work in the process of compiling the legislative planning of the city by means of statistical analysis and literature research. In other words, the application of the precise definition of the scope of legislation, multi-generation legislation projects, fully demonstration the legislative projects and the preparation of legislative points is expected to contribute to the work of this legislation.
\end{abstract}

Keywords-the legislation of the city, the planning of the legislation, project demonstration, planning procedures

\section{INTRODUCTION}

The modification of the "legislation law" has increased the legislative power of the city in 2015. Therefore, most of the cities are still blank in local legislation. This paper is the research and demonstration of this blank, which makes the local legislation more scientific and reasonable, especially in the Legislation planning work. In order to achieve the local scientific legislation and correspond to the requirement of 'legal country', this paper provides feasible recommendations through the interpretation of legislation related laws and regulations, the relevant academic theory and other urban legislative experience. Meanwhile, as an applied and practical scientific research, this paper hopes to produce universal research results to provide a reference to other cities.

Under the background of advancing the rule of law, the exploration of the planning work of the Municipal People's Congress can make it possible to manage the specific areas of affairs with local characteristics, so as to have a positive effect on promoting the construction of the rule of law and the local legislative process, to carry out local legislation, to make detailed legislative arrangements to fill the gaps in local legislation and to promote and accelerate the city's legislature to develop high-quality local laws and regulations. We will promote the construction of the rule of law by making scientific legislation in the context of comprehensively promoting the rule of law and promoting the scientific and applicability of local legislation, so as to manage the local affairs.

\section{DEFINE THE SCOPE OF THE LEGISLATION OF THE CITY}

The article 72 of the Legislative Law stipulates that "the Municipal People's Congress may formulate local laws and regulations on matters such as urban and rural construction and management, environmental protection, and historical and cultural protection." This provision is very general and uncertain, what does "urban and rural construction and management, environmental protection, historical and cultural protection "include?

\section{A. "Urban management"}

The city management mainly refers to the government departments of public facilities, public utilities and municipal construction control and arrangements. Combined with the background of the modification of 'legislation law', urban and rural construction and management mainly include:

- Urban and rural planning, because plan makes construction and management possible.

- Real estate and public works;

- Energy supply and water management, such as power supply, heating, gas supply, water supply, drainage, etc. .;

- City health,

- Transportation, such as passenger and cargo transport management, taxi management, road and bridge management, port airport management, etc. .;

- Post and telecommunications, such as radio and television, fixed telephone, Internet and so on.

- Geological weather disaster prevention, such as flood control, wind, fire, earthquake, etc. .;

- Other urban and rural construction and management related matters.

\section{B. Environmental Protection Act}

The 'Environmental Protection Act' stipulates that "protect and improve the environment, prevent different kinds of pollution, and promote the construction of ecological civilization." In addition, the United Nations "Human Declaration" pointed out the environmental issues, including environmental pollution and ecological damage. Thus, the 
author summarized the legislative scope of the environmental protection as the following categories:

- Atmospheric environmental problems, such as industrial emissions, automobile exhaust emissions, living emissions, dust control;

- Water environmental problems, such as industrial wastewater discharge, domestic sewage discharge, river lake protection, water source protection;

- Solid waste disposal problems such as slag disposal, industrial solid waste treatment, slag treatment, domestic waste disposal, waste disposal, etc.;

- Land environmental problems such as land pollution, soil degradation, farmland transformation, wasteland utilization, etc. .;

- Marine environmental problems, offshore oil pollution, thermal pollution and solid waste pollution, metal acid pollution, overfishing;

- Forest protection Problem, transitional logging, forest fire prevention, artificial foresting, etc.;

- Grassland protection issues, overgrazing, overgrowth, grassland degradation, etc.;

- Wildlife protection problems, wildlife species reduction, biological invasion, wildlife use, etc.;

- Other environmental issues.

\section{History and cultural protection}

History and cultural protection is a broader concept, what is the history and culture? The generalized history and culture refers to the sum of the social spiritual culture and the material culture in a certain period. The narrow historical culture only refers to the spiritual culture of a certain period. Therefore, the author simply summarized the history and culture as follows: cultural relics, scenic spots, folk customs, religion, celebrity works, traditional crafts, dress, folk music, folk dance, rap, acrobatics, dialect, dialect, proverb and so on.

\section{Some scholars have questioned, how to understand the Article 72 of the "Legislative Law" of the three issues behind the "and so on"?}

Is "equal and other" or "other and other "For this controversy, Li Shu-shi, director of the Standing Committee of the Standing Committee of the National People's Congress, clearly stated that it's 'equal and other' here .Therefore, we should adhere to the "equal and so on" and set the city's legislative planning within the control of the three plates .

\section{LEGISLATION PROJECT}

Legislation recommended that the legislative intentions and legislative requirements of the public. The collection and the demonstration of the proposals become a project. According to the survey, the author found that the legislation of the provincial or provincial capital and the larger cities mainly declared by the government departments. The existence of legislative project declaration system cannot objectively reflect the local public opinion, lose legislation targeted quality and the poor quality of legislative projects. In order to make up the shortcomings that only the government and functional departments can declare, the author proposes the following channel conception of the legislative project.

\section{A. The Municipal People's Congress put forward legislative projects.}

The proposal of the legislation project is determined by the legislation messages and The nature of the, municipal people's congress itself also determines the breadth of its discovery of legislative information.

- The municipal people's congress deputies makes suggestions, comments, criticisms or proposals to find legislative information;

- The municipal people's congress listens to a government work report or special report to find legislative information;

- People's Congress accepts the people's complaints to obtain legislative information. After obtaining and sorting out the legislative information, it is considered to be the scope of legislation in the district, which can be demonstrated to produce legislative projects.

\section{B. Government and functional departments to declare legislative projects.}

Government and functional departments are managers, law enforcement, and thus can find the social problems more extensive, if these problems do need to be resolved through legislation, legislative projects can be proposed accordingly. "Neijiang City Local Legislation Ordinance" stipulates that the Municipal People's Government should put forward legislative proposals in written form, the proposal should include the name of local laws and regulations, the necessity and feasibility of legislation, the main problems to be solved and the proposed system content. Although some scholars pointed out that the government and functional departments to declare the legislative project system has drawbacks, we cannot deny the superiority of its declaration of legislative projects, such as the extensive access to legislative information, the legislative project of professionals, the legislative project feasibility, so the traditional legislative project reporting system should hold on.

\section{Collecting legislative projects from social groups.}

Social groups are mainly industry associations, societies, seminars, associations, fraternities, federations, foundations, chambers of commerce and so on. Social groups have their own interests, so their participation in legislation is often higher. In view that the social groups have their own funds and certain professionals, they can submit written legislative proposal usually referring to the municipal government and functional departments and can provide the necessary assistance to the Municipal people's congress. 


\section{Collecting advice on legislative projects from the public.}

Democratic legislation is one of the important principles of legislation. It is the embodiment of democratic legislation to collect legislation proposals from the public. At the same time, citizens, legal persons or other organizations are managed, and their interest demands and legislative expressions should be reflected more. The Citizens, legal persons or other organizations are different from the government and functional departments, social groups have professionals, activities and funds, so we cannot require them propose specific laws and regulations, feasibility and necessity of the feasibility study report and other specific legislative projects. They only need to propose some suggestions on legislative projects, but the legislative project proposal should try to explain the name of the law, the necessity of legislation, laws and regulations to solve the problem, as well as the content and basis of the law. The Municipal People's Congress sorts out these legislative proposals, finds out most pressing legislative proposals of the public, demonstrates them, forms a legislative project and makes it open to the public.

\section{PROJECT DEMONSTRATION}

In order to ensure the legitimacy, scientific degree and feasibility of the legislation of the city, it is necessary to establish a system of combining expert argumentation with joint demonstration, ensuring the source of legislation.

\section{A. Expert argument .}

The People's Congress commissioned scientific research institutions and learning professional researchers to demonstrate the legislative project. From 2013 to 2017, the Municipal People's Congress in shanghai commissioned the Shanghai Academy of Social Sciences to screen the 255 projects respectively and put forward a written report. Conditional city can learn from this example. The contents of the expert argument mainly include the following aspects:

- Whether the project is within the scope of the "legislative law";

- Whether the conflict with the central legislation, provincial legislation and so on;

- Whether the current central guidance spirit, such as decentralization, paying attention to post-regulation

- Whether there are maintenance department interests or local protectionism, the projects with the interests of the sector, industry monopoly, local protectionism are not included in the legislative planning.

\section{B. Joint demonstration.}

All members of the Municipal People's Congress Law Committee, the main leadership of the city government legal office, part of the Municipal People's Congress, the experts in the field of demonstration, part of the judicial staff and legal experts form a demonstration group and make legislative project demonstration. Arbitration requires the companies to prepare carefully and answer the questions on the spot.
- What issues should legislation be addressed;

- Whether the legislative conditions are ripe;

- Whether the issues involved have reached the extent that they have to be resolved by legislative means;

- Whether the existing laws and regulations are relevant to the key issues to be addressed;

- Whether the key issues have the creative terms.

\section{C. legislative project repository}

Classifying all the legislative projects above, such as the more urgent legislative projects, the mature and immature legislative projects, and finally electing the legislative projects to the legislative project repository.

\section{PlANNING PROCEDURES}

\section{A. Preparation of draft legislation.}

First, determine the name of the legislative plan. With reference to the name of the central legislative plan, the name of the legislative plan of the city can be defined as "the five-year plan (20XX 20XX annual) of the Municipal People's Congress on local regulations." Second, determine the content of legislative planning. The legislative project is the core content of the legislative plan, in accordance with the priority of the urgent need to legislate, the implementation of national legislation or provincial legislation projects, the public strongly appealed legislative projects; the legislation which conditions are not yet mature and need to fully demonstrate become the projects on process. Finally, the Municipal people's congress writes a report on the work of the legislation.

\section{B. Consideration, adjustment and publication of the draft.}

The people's congress Law Committee shall submit the draft plan and the work report to the General Assembly or the Standing Committee for consideration. The main contents considered are:

- Whether the planning is legal, feasible, scientific;

- Whether the name and the content of the plan is appropriate, mainly whether the arrangement of the legislative projects, demonstration and description are legal, feasible and scientific;

- Whether the projects have faults which deviate from the socialist democracy and the rule of law. After the deliberation, if it's necessary to make appropriate changes and adjust the projects, the people's Law Committee needs to adjust and get approval from the General Assembly or the Standing Committee again. After approving the legislative plan, the people's congress announces this legislative plan.

\section{CONCLUSION}

The legislative work of the National People's Congress is the main basis for the legislative work of the city. Relevant departments and individuals should actively participate in proposing legislative suggestions, and people who reach the 
level can submit drafts of legislation. For the collected legislative proposals, the NPCSC should follow the principles of science and democracy to demonstrate the legitimacy, feasibility and necessity, and give the results of the report to the Municipal People's Congress Standing Committee to discuss the decision.

\section{REFERENCES}

[1] Cheng Qingdong: "the legislative power of the district: the scope of authority and the exercise of power," [J], "Politics and Law", the eighth issue of 2015(in chinese).

[2] Peng Heping, Hou Shusen: "Urban Management" [M], Higher Education Press, 2009 edition, p. 8(in chinese)

[3] Mao Xi: "theory and method of historical and cultural geography", [J], "Journal of Shaanxi Normal University", 2002 the third period(in chinese).
[4] Hou Mingxin: "set the city of legislative authority of the clarity and ambiguity," [J], "Legal Expo", 2016, No. 8(in chinese).

[5] Li Shiwei: "the full implementation of the revised legislative law", [Z], in the twenty-first national local legislative seminar summary(in chinese).

[6] Zhou Wei: "on the local legislative project collection system perfect", [J], "Journal of Jianghan University", the first issue of 2016(in chinese).

[7] Liu Jinsen: "local legislation project access to information", [J], "Xinjiang People's Congress", 2010 No. 3(in chinese).

[8] Wu Zhuowen: "written in the Henan Provincial People's Congress Standing Committee to open up the legislative project days", [Z], "power organs tour", July 2003(in chinese).

[9] Zhuang Honglei: Wang Congzhong: "set up the city of legislative proceedings", [J], "Journal of Lianyungang Vocational and Technical College", No. 2016, No. 3(in chinese)

[10] Yao Jian: "scientific arrangements for legislative projects is an important part of the work of government legislation," [J], "Fujian theoretical study", 2014, No. 11(in chinese) 